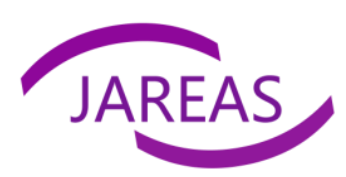

DOI: https://doi.org/10.47631/jareas.v2i2.235

\title{
Corporate Diversification and Financial Performance of Listed Firms in Kenya: Does Firm Size Matter?
}

\author{
Peninah Jepkogei Tanui ${ }^{1}$, Bramwel Murgor Serebemuom ${ }^{2}$ \\ 1Alupe University College, Kenya \\ 2Kisii University, Kenya
}

\begin{tabular}{l} 
Article Info \\
Article history: \\
Received:18 February 2021 \\
Revised: 28 April 2021 \\
Accepted: 28 April 2021 \\
Keywords: \\
Corporate Diversification \\
Firm Age \\
Firm Size \\
Financial Performance \\
JEL: G32, H21, C33, O54, \\
G30. \\
Paper Type : \\
Research Article \\
\hline Corresponding Author: \\
Dr. PeninahJepkogeiTanui \\
Email: \\
tanuipenina@gmail.com
\end{tabular}

Abstract
Purpose: The study tested the hypothesis about the relationship between
corporate diversification and financial performance. Moreover, moderating
effect of firm size on the relationship between corporate diversification and
financial performance of listed firms at Nairobi securities exchange (NSE) in
Kenya was tested.

Methodology/Approach/Design: The study was informed by market power and resource-based view (RBV) theories. To test the hypotheses, secondary panel data were collected from 35 listed firms at NSE from 2003 to 2017.

Results: From panel regression analysis output, there was a significant positive $(\beta=2.225$, $p$ value $=.000<.05)$ relationship between corporate diversification and financial performance. Furthermore, firm size had a negative and significant $(\beta=-.155, p$ value $=.031<.05)$ moderating effect in the relationship between corporate diversification and financial performance. Practical Implications: The study thus concluded that firm size had a buffering effect in the link between corporate diversification and the financial performance of listed firms in Kenya. The findings of the study could be relevant to policymakers in drafting policies that affect diversification strategies of firms. For further research, the study recommended an increase of scope, other measurement approaches, analysis of corporate diversification from different perspectives other than product, and controlling for board characteristics.

Originality/Value: The study while controlling the age of the firm tested the moderation effect of firm size in the relationship between corporate diversification and financial performance.

\section{Introduction}

In most listed firms, shareholders aim to take full advantage in advancing their wealth which mainly depends on performance. As a result, a firm's performance is explained better given its ability to utilize the resources(Graham, 2010) which in turn generates more economic benefits in the future. In the present years, the performance of the firm not only matters to the shareholders but also stakeholders. This has forced the management of most firms to change from shareholder to stakeholder view of the firm. To fulfill the needs of its owners and stakeholders, managers are expected to comprehend firm performance given key determinants. According to Almajali, Alamro, \& Al-Soub (2012), the performance of the firm is affected by both internal and external factors. Despite putting forth proper financial management practices, diversification inform of either international, product, geographic, related, or unrelated add to the list as an essential building block in advancing firm performance(Hunjra, 2010). From Harry Markowitz's modern portfolio theory perspective, diversification is used as a line of attack to diminish risks while maximizing returns in the firm. Other than reducing risks, corporate diversification as opined by 
(Shyu \& Chen, 2009) enables a firm to seek out growth opportunities in the pursuit of enhancing the going concern. Empirically, corporate diversification has been found to positively impact financial performance (Krivokapic, 2017; Kenyoru, 2016; Mehmood, 2019).

Generally, the amounts of resources are vital in determining the attainment of strategies laid down by the firm. In addition, the size of the firm is gauged based on the resources it owns leading to the categorization of the firm as either large or small. Firm size has been termed as a key resource as far as diversification plans in the firm are concerned (Chatterjee \& Wernerfelt, 1991). Indeed, resources have been termed as a driving force as those with more are likely to engage in diversification (Nath, Nachiappan, \& Ramanathan, 2010). As explained well in resource-based view (RBV) theory, both tangible and intangible assets are part of the resources enabling a firm to diversify and reap more gain in addition to earning economies of scope. According to Montgomery (1994), diversification in a firm occurs in an attempt to utilize excess resources. Consequently, large firms in terms of the assets owned tend to expand more to generate more profits (Untoro \& Rahardian, 2015). In the same vein, Phung \& Mishra (2016) point out that firm size has a significant impact on corporate diversification as well as financial performance. In terms of financial performance, there exists variation given the existence of loss and profit-making listed firms across sectors in Kenya. Moreover, listed firms differ in their sizes even though they all meet the listing required by the Nairobi Securities Exchange (NSE). There is a need to consider the interaction effect of firm size notwithstanding the level of performance expected through the implementation of diversification. First and foremost, the study seeks to test $\mathrm{H}_{01}$; there is a significant relationship between corporate diversification and the financial performance of listed firms at NSE in Kenya. Lastly, the study aims to test $\mathrm{H}_{\mathrm{o} 2 \text {; firm }}$ size moderates the relationship between corporate diversification and financial performance of listed firms at NSE in Kenya.

\section{Literature Review}

The study was anchored on market power theory by Cynthia Montgomery in 1994. The theory sets forth a positive relationship between corporate diversification and financial performance. This is so given that market power is earned through diversification which in turn advances the performance of the firm. Market power theory thus formed the foundation of conceptualization of the relationship between corporate diversification and financial performance of listed firms in Kenya. RBV theory by Edith Penrose in 1959 affirms the existence of valuable resources in most firms. As a result, the 'bundle of resources' contributes more to the uniqueness of a firm. As a result, more benefits in terms of financial performance can be derived by the firm once it takes advantage of resources available to diversify. Hence, RBV theory forms the basis of conceptualizing firm size in corporate diversification-financial performance nexus.

Copyright (C) 2021, Journal of Advanced Research in Economics and Administrative Sciences (JAREAS), Under a 


\section{Hypotheses Development}

Corporate diversification has been used by most firms to progress performance. Therefore, despite being an old concept in the corporate finance world (Li \& Zhang, 2007), diversification remains vibrant. Given the number of risks involved. Seifi et al. (2012) pointed out the suitable progression of corporate diversification. These include the identification stage of all investment opportunities followed by an assessment of their market attractiveness. In the last step, Seifi et al., (2012) elucidate the need for evaluation of success factors attributed to the new venture adjacent to the investment opportunities, firm competencies, and capabilities. Other than outlined process of corporate diversification, firms utilizing internal as opposed to external financing succeed with their diversification plans (Lins \& Servaes, 2002). This is attributed to the fact that costs arising due to the use of external capital are avoided thereby promoting the positive link between diversification and firm value.

Over time, researchers have opted to demystify the effect of corporate diversification on the performance of firms in different sectors. To begin with, 40 listed firms regardless of their sectors were analyzed by (Iqbal, Hameed, \& Qadeer, 2012) in Pakistan. After analysis of data collected from 2005 to 2009, there was no impact of corporate diversification on financial performance. In conclusion, Iqbal et al. (2012) summed that all firms whether less, moderately, or highly diversified performed equally. Akpinar \& Yigit (2016) analyzed data of firms in the Netherlands, Italy, and Turkey to examine the diversification strategy on performance. For firms sampled from Italy and Netherlands, there was no correlation reported between the study variables. On the other hand, analyzed data from Turkish firms demonstrated a low but positive correlation between diversification and financial performance. The relationship between diversification and performance of listed firms in Vietnam was found to be negative (Phung \& Mishra, 2016). Lastly, Salma \& Hussain (2018) documented the significant impact of corporate diversification on the financial performance of 465 firms from India, Sri Lanka, and Pakistan.

In the Insurance sector, Pavić \& Pervan (2010) sampled 4 non-life insurance companies in Croatia. After analyzing data collected from 2004 to 2007, insurance performance was negatively affected by diversification. Indeed, the study concluded that undiversified had superior performance than diversified firms even though they were categorized as one sector. Krivokapic et al. (2017) analyzed the effect of corporate diversification on the financial performance of 23 insurance companies in Serbia. After analysis of data collected from 2004 to 2014, there was a positive relationship between product diversification and financial performance. Doaei et al. (2014) investigated 102 manufacturing firms listed from 2006 to 2010 in Malaysia. In this study, there was no significant relationship between financial performance given both product and unrelated diversification. On the other hand, related and international diversification as observed by (Doaei et al., 2014) negatively impacted performance. A total of 520 manufacturing firms operating in Pakistan, India, Sri Lanka, and Bangladesh were targeted by (Mehmood et al., 2019). Using a two-step dynamic panel approach, product and geographic diversification had a significant impact on financial performance.

Copyright (C) 2021, Journal of Advanced Research in Economics and Administrative Sciences (JAREAS), Under a Creative Commons Attribution 4.0 International License 
Using data of 2372 banks from 29 Asian Pacific countries, Lee et al. (2014) found out that revenue diversification improved performance. Kenyoru et al.(2016) examined product diversification of commercial banks in Kenya's Kericho town into three levels namely horizontal, vertical, and conglomerate. The study found a positive impact on financial performance as the levels of product diversification increased. In France, Jouida, Bouzgarrou, \& Hellara (2017) examined the corporate diversification of 412 financial institutions in relation to their financial performances. From the analysis, both activity and geographic diversification reduced firms' ROA. Manyuru et al., (2017) studied 38 listed firms under the finance, real estate, and insurance sector in Kenya. The main aim was to assess the effect of corporate diversification (industrial and geographic) on financial performance. In the last part,(Manyuru et al., 2017) found the two levels of diversification as having no and negative impact on Tobin's q. In the construction sector, Oyekunle et al., (2013) found out that both product and geographic diversification among 62 contracting firms positively affected financial performance. From the reviewed related studies, mixed findings regarding the relationship between corporate diversification and the financial performance of firms are evident. Despite the studies carried out in Kenya, the study used a different methodology in analyzing listed firms in all sectors. Therefore, the study hypothesized that;

Hol; there is a significant relationship between corporate diversification and financial performance of listed firms at NSE in Kenya

Agency theory explains the agency relationships that exist given the managers (agents) of the firm and principals (shareholders). As per the proponents of this theory, therefore, most managers like to be associated with large firms. As a result, they will work round the clock in increasing the firm size to fulfill their selfish interests at the expense of the shareholders. Moving away from this, firm size has been examined in relation to financial performance. To begin with, Montgomery (1994) in resource view proposed a positive link between corporate diversification and financial performance. Jónsson (2007) in Iceland reported that large firms had higher profitability compared to smaller firms. Lee 2009 used a fixed-effect dynamic panel data model to analyze data of public firms in the United States (US). It was established that firm size had a positive impact on profitability. In the same country, Becker-Blease et al., (2010) analyzed data of manufacturing firms from 1987 to 2002 . Firm size, in this case, was defined using total assets, total sales, and the number of employees of firms. Contrary to Lee's (2009)findings, there was a negative relationship between firm size and profitability. Vijayakumar \& Tamizhselvan (2010) examined the effect of firm size on the profitability of 15 companies in South India. In this study, firm size using total sales and assets while performance was indicated by profit margin and ratio between profit and total sales. A positive relationship was later found between firm size and profitability. Furthermore, firm size has been found to enhance financial performance listed firms in Nigeria (Babalola, 2013), Turkey (Doğan, 2013), Pakistan (Ghafoorifard, Sheykh, Shakibaee, \& Joshaghan, 2014), and Sri Lanka (Niresh \& Thirunavukkarasu, 2014). RBV theory asserts that resources in terms of large assets help firms implement strategies to expand their segments. As a result, the more the resources, the higher the size of the firm which in turn drives forth diversification (Chatterjee \& Wernerfelt, 1991; Nath et al., 2010; Untoro \&

Copyright (C) 2021, Journal of Advanced Research in Economics and Administrative Sciences (JAREAS), Under a 
Rahardian,2015). Regardless of the commendable studies relating the firm size to both corporate diversification as well as performance, a gap was found to exist. The study thus sought to determine the moderating effect of firm size in the relationship between corporate diversification and financial performance. In this view, it was hypothesized that;

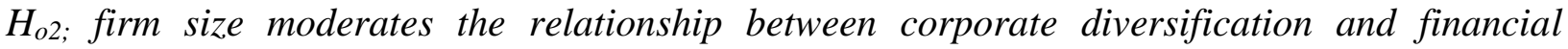
performance of listed firms at NSE in Kenya

\section{Conceptual Framework}

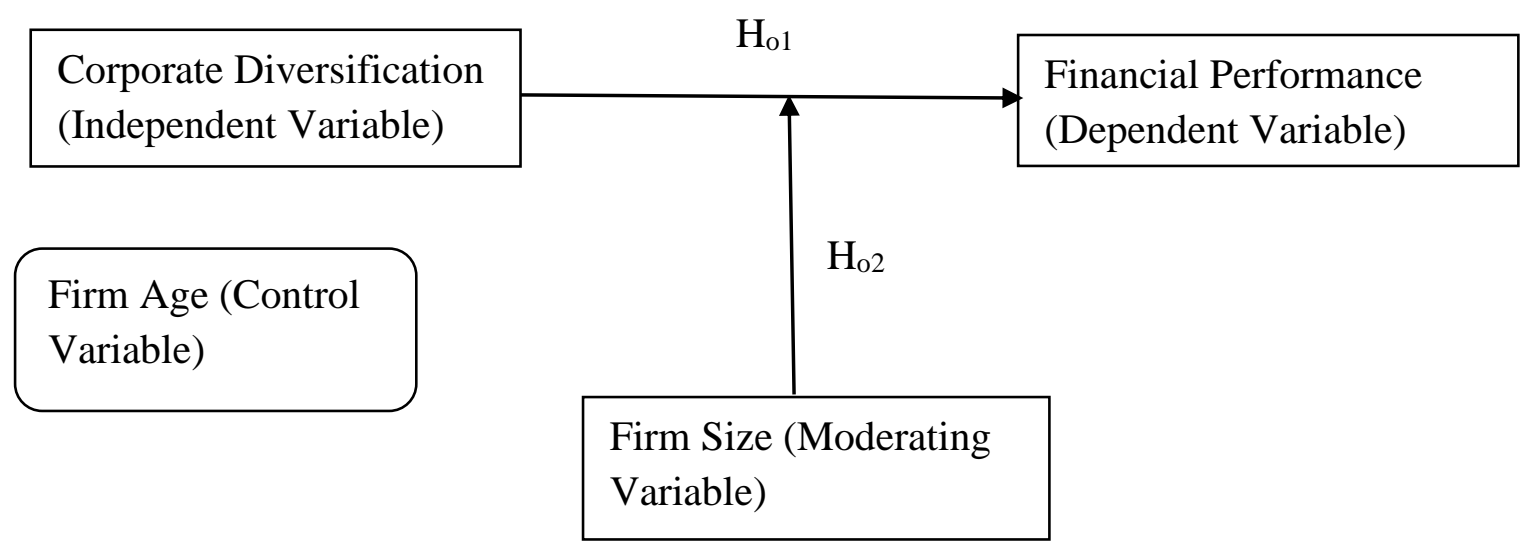

Figure 1; Conceptual Framework of the Study

\section{Methodology and Procedures}

The study is framed within a post-positivist research philosophical foundation. The explanatory research design was appropriate helping to examine the relationship between the study variables (Zikmund et al., 2013). A total of 65 listed firms in all sectors at NSE in Kenya were targeted. However, after inclusion and exclusion criteria, secondary panel data were collected from 35 listed firms from 2003 to 2017. Data analysis comprised of testing for correlation, regression assumptions, panel unit root test, and finally testing of hypotheses using panel regression analysis. The regression models were as follows;

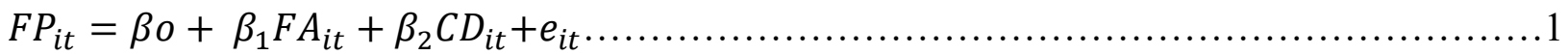

$F P_{i t}=\beta o+\beta_{1} F A_{i t}+\beta_{2} C D_{i t}+\beta_{3} F S_{i t}+\beta_{4}(F S *$

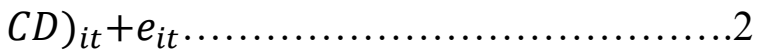

Key; FP (financial performance); FA (firm age); FS (firm size); CD (corporate diversification); $\beta$ o (intercept); $\beta_{1}$ to $\beta_{4}$ (beta coefficients); e (random error term). 


\section{Results and Discussion}

Table 1: Measurement of Study Variables

\begin{tabular}{|c|c|c|}
\hline Variable & Measurement & \\
\hline $\begin{array}{l}\text { Financial Performance } \\
\text { (Dependent variable) }\end{array}$ & $\begin{array}{l}\text { Modified Tobin's q by Chung } \\
\text { and Pruitt (1994) }\end{array}$ & $\begin{array}{l}\text { uru et al., 2017);(Saleh, } \\
\text { lin, \& Octaviani, 2017) }\end{array}$ \\
\hline $\begin{array}{l}\text { Corporate Diversification } \\
\text { (Independent Variable) }\end{array}$ & $\begin{array}{l}\text { Jacquemin and } \\
\text { Entropy measure. }\end{array}$ & $\begin{array}{l}\text { (Akpinar \& Yigit, 2016); } \\
\text { (Krivokapic et al., 2017) }\end{array}$ \\
\hline $\begin{array}{l}\text { Firm Size } \\
\text { Variable) }\end{array}$ & $\begin{array}{l}\text { Natural logarithm of total } \\
\text { assets owned by the firm }\end{array}$ & $\begin{array}{l}\text { (Krivokapic et al., 2017); (Nzioka, } \\
\text { 2017); (Salma \& Hussain, 2018) }\end{array}$ \\
\hline $\begin{array}{l}\text { Firm Age } \\
\text { Variable) }\end{array}$ & $\begin{array}{l}\text { Number of years since the } \\
\text { firm was listed }\end{array}$ & $\begin{array}{l}\text { (Oyekunle Oyewobi et al., 2013); } \\
\text { (Doaei et al., 2014) }\end{array}$ \\
\hline
\end{tabular}

Source; Conceptualization by the researcher (2019)

\section{Descriptive Statistics and Correlation Analysis}

In Table 2, financial performance $(\mathrm{FP})$ maximum of 29.83 (Mean $=1.21$, standard deviation $=$ 2.02) indicates that Tobin's q ratio was greater than 1. This implied that there were better investment opportunities, high potential growth, and overvalued stock compared to the firms with the minimum value of -.033. On the other hand, the mean and standard deviation for corporate diversification (CD) was found to be 0.59 and 0.41 respectively. Given the minimum value of CD (0.00), it implied that some listed firms at NSE had no diversification plans. Firm size (FS) of listed firms studied differed given the minimum and maximum of 19.69, 27.20 respectively. In terms of the firm age (FA), the least number of years since listed were 2 compared to 67 years on the higher end.

Table 2: Descriptive Statistics and Correlation Analysis Results

\begin{tabular}{lllllllll}
\hline & Mean & $\begin{array}{l}\text { Standard } \\
\text { Deviation }\end{array}$ & Minimum & Maximum & FP & CD & FS & FA \\
\hline FP & 1.21 & 2.02 & -0.33 & 29.83 & 1 & & & \\
CD & 0.59 & 0.41 & 0.00 & 1.52 & $-.324^{* *}$ & 1 & & \\
FS & 23.32 & 1.66 & 19.69 & 27.20 & $-.240^{* *}$ & $.369^{* *}$ & 1 & \\
FA & 34.11 & 15.23 & 2 & 67 & .030 & -.063 & $-.106^{*}$ & 1 \\
\hline
\end{tabular}

** Correlation is significant at the 0.01 level (2-tailed)

Source: Researcher's data, 2019

From the results in Table 2, the correlation between CD and FP was $r=-0.324$ and significant. This indicated that corporate diversification plans implemented by the listed firms negatively affected their performance. The correlation between FS and FP was found to be significantly negative but weak as indicated $r=-0.240$. Basing on the positive but insignificant correlation between FA and FP $(r=0.30)$, the number of years since the firm was listed positively improved its financial performance. The association between FA and CD among listed firms in Kenya was a negative association $(r=-0.063)$ but not significant. However, FS and CD had a positive and significant relationship. The possible explanation was that the size of the firm was

Copyright (C) 2021, Journal of Advanced Research in Economics and Administrative Sciences (JAREAS), Under a 
vital in increasing diversification. There was a significant weak and negative correlation between FA and FS as indicated by $r=-0.106$. This implied that the management of older compared to newly listed firms made decisions that negatively affected the size of the firm.

\section{Diagnostic and Panel Unit Root Test}

Table 3: Diagnostic and Panel Unit Root Test

\begin{tabular}{|c|c|c|c|c|c|c|}
\hline \multirow[t]{2}{*}{ Variable } & \multicolumn{2}{|c|}{ Panel Unit Root Test } & \multirow{2}{*}{$\begin{array}{l}\text { Normality } \\
\text { test } \\
\text { Shapiro- } \\
\text { Wilk test } \\
\text { p-values }\end{array}$} & \multirow{2}{*}{$\begin{array}{l}\text { Multicollinearity } \\
\text { test } \\
\text { Variance } \\
\text { inflation factor } \\
\text { (VIF) values }\end{array}$} & \multirow{2}{*}{$\begin{array}{l}\text { Homoscedasticity } \\
\text { test } \\
\text { Breusch- } \\
\text { Pagan/Cook- } \\
\text { Weisberg test p- } \\
\text { values }\end{array}$} & Autocorrelation \\
\hline & $\begin{array}{l}\text { Levin- } \\
\text { Lin-Chu } \\
\text { (LLC) test } \\
\text { (p-values) }\end{array}$ & $\begin{array}{l}\text { Im- } \\
\text { Peseran- } \\
\text { Shin } \\
\text { (IPS) } \\
\text { test (p- } \\
\text { values) }\end{array}$ & & & & $\begin{array}{l}\text { Durbin Watson } \\
\text { statistic }\end{array}$ \\
\hline FP & .000 & .000 & & & & \\
\hline CD & .001 & .000 & .08 & 3.42 & .06 & \\
\hline FS & .000 & .000 & .11 & 1.67 & .82 & \\
\hline FA & .000 & .000 & .60 & 5.48 & .77 & 2.170 \\
\hline
\end{tabular}

Source: Researcher's data, 2019

Basing on the results of LLC and IPS tests in Table 3, panel data was stationary since all the pvalues were less than the level of significance. As a result, no unit root was found which affects statistical inference. Regression assumptions tested were normality, multicollinearity, homoscedasticity, and autocorrelation. First and foremost, normality existed as p-values for Shapiro- Wilk tests were greater than the level of significance. Secondly, there was no single independent variable that was highly correlated within a set of other independent variables since VIF values were less than 10 . Variances of residuals were equally distributed across the values of predicted values as indicated by homoscedasticity test results. Lastly, residuals were independent as the Durbin Watson statistics were within the acceptable range of between 2 and 4. This, therefore, led to the conclusion that there was no autocorrelation.

\section{Testing of Hypotheses}

In panel data, there is a need to test whether a fixed and random effects model is appropriate. In this case, all time-invariant differences between individuals are controlled by the fixed effect model (Stock \& Watson, 2003; Bickel, 2007). The random effect model uses both within and between variances to control for individual-specific variations. Using the Hausman specification test, the Chi-square test statistic was 30.22 with a p-value of .000 . This led to the rejection of the null hypothesis (random-effects model is appropriate). This implied that the fixed-effects model was appropriate. In Table 4, R-squared was .492 implying that $49.2 \%$ of variations in financial performance were explained by corporate diversification (CD). The study found had a significant negative relationship between FA (firm age) and CD as indicated by $\beta=-.088$ and pvalue $=.000<.05$. Accordingly, one unit change in firm age led to a decrease in financial performance by 0.088 units. Therefore, older firms in terms of years since listing perform

Copyright (C) 2021, Journal of Advanced Research in Economics and Administrative Sciences (JAREAS), Under a 
poorly. This could be explained by the fact that management of such firms fails to adopt new strategies to improve financial performance, unlike newly listed firms.

Table 4: Testing Hypothesis for the Direct Effects

Dependent Variable: FP

Method: Panel Least Squares

Sample: 20032017

Periods included: 15

Cross-sections included: 35

Total panel (balanced) observations: 525

\begin{tabular}{crrrr} 
Variable & Coefficient & Std. Error & t-Statistic & Prob. \\
\hline C & 4.083 & 0.585 & 6.979 & 0.000 \\
FA & -0.088 & 0.018 & -4.830 & 0.000 \\
CD & 2.225 & 0.374 & 5.951 & 0.000 \\
\hline R-squared & 0.492 & & & \\
Adjusted R-squared & 0.487 & & & \\
\hline
\end{tabular}

Source: Researcher's data, 2019

There was a positive $(\beta=2.225)$ and significant $(\mathrm{p}$-value $=.000<.05)$ relationship between financial performance and corporate diversification. This finding meant that 1 unit change in corporate diversification increased financial performance by 2.225 units. In this regard, Ho1; there is a significant relationship between corporate diversification and financial performance of listed firms at NSE in Kenya was rejected. Consequently, there was a significant relationship between corporate diversification and financial performance. In this case, corporate diversification was defined based on product and gauged using Entropy measure. The study thus supported (Oyekunle Oyewobi et al., 2013), (Krivokapic et al., 2017) and (Mehmood et al., 2019) who specifically found a positive relationship between product diversification and financial performance.

Table 5: Testing of Hypothesis for Moderation Effects

Dependent Variable: FP

Method: Panel Least Squares

Sample: 20032017

Periods included: 15

Cross-sections included: 35

Total panel (balanced) observations: 525

\begin{tabular}{crrrr} 
Variable & Coefficient & Std. Error & t-Statistic & Prob. \\
\hline FA & 0.003 & 0.006 & 0.545 & 0.586 \\
FS & 0.086 & 0.011 & 7.100 & 0.000 \\
CD & 2.130 & 1.748 & 1.219 & 0.224 \\
FSCD & -0.155 & 0.079 & -2.160 & 0.031 \\
\hline
\end{tabular}

R-squared

0.421

Copyright (C) 2021, Journal of Advanced Research in Economics and Administrative Sciences (JAREAS), Under a Creative Commons Attribution 4.0 International License 
Before testing the moderation effect, Table 5 indicated that firm size (FS) had a positive and significant $(\beta=.086, p$-value $=.000<.05)$ relationship with the financial performance of listed firms at NSE in Kenya. Hence, one unit change in firm size increased financial performance by 0.086 units. The finding thus was in tandem with those by (Babalola, 2013), (Doğan, 2013), (Ghafoorifard et al., 2014) and (Niresh \& Thirunavukkarasu, 2014). In addition, there was a positive $(\beta=2.130)$ and insignificant ( $p$-value $=.224<.05)$ relationship between corporate diversification (CD) and financial performance (FP). After the interaction between FS and CD (FSCD) in Table 5, FS had a negative $(\beta=-.155)$ and significant ( $\mathrm{p}$-value $=.031<.05)$ moderate the relationship between corporate diversification (CD) and financial performance (FP).

The study had hypothesized in $\mathrm{H}_{\mathrm{o} 2}$ that firm size moderates the relationship between corporate diversification and financial performance of listed firms at NSE in Kenya. Following the interaction results, the null hypothesis was rejected and concluded that firm size did moderate the relationship between corporate diversification and financial performance of listed firms at NSE in Kenya. At low levels of CD in Figure 2, financial performance (FP) of listed firms with high FS was higher compared to those with low levels of FS. Alternatively, at high levels of CD, the FP of firms with high levels slightly declined. More importantly, the relationship between $\mathrm{CD}$ without interaction with FS was positive as shown by the coefficient estimate of 2.130. Once interaction was done between FS and CD, the relationship with the financial performance of listed firms decreased from 2.130 to -.155 . Therefore, firm size was a buffering moderator since it's decreased the effect of corporate diversification on the financial performance of listed firms at NSE in Kenya.

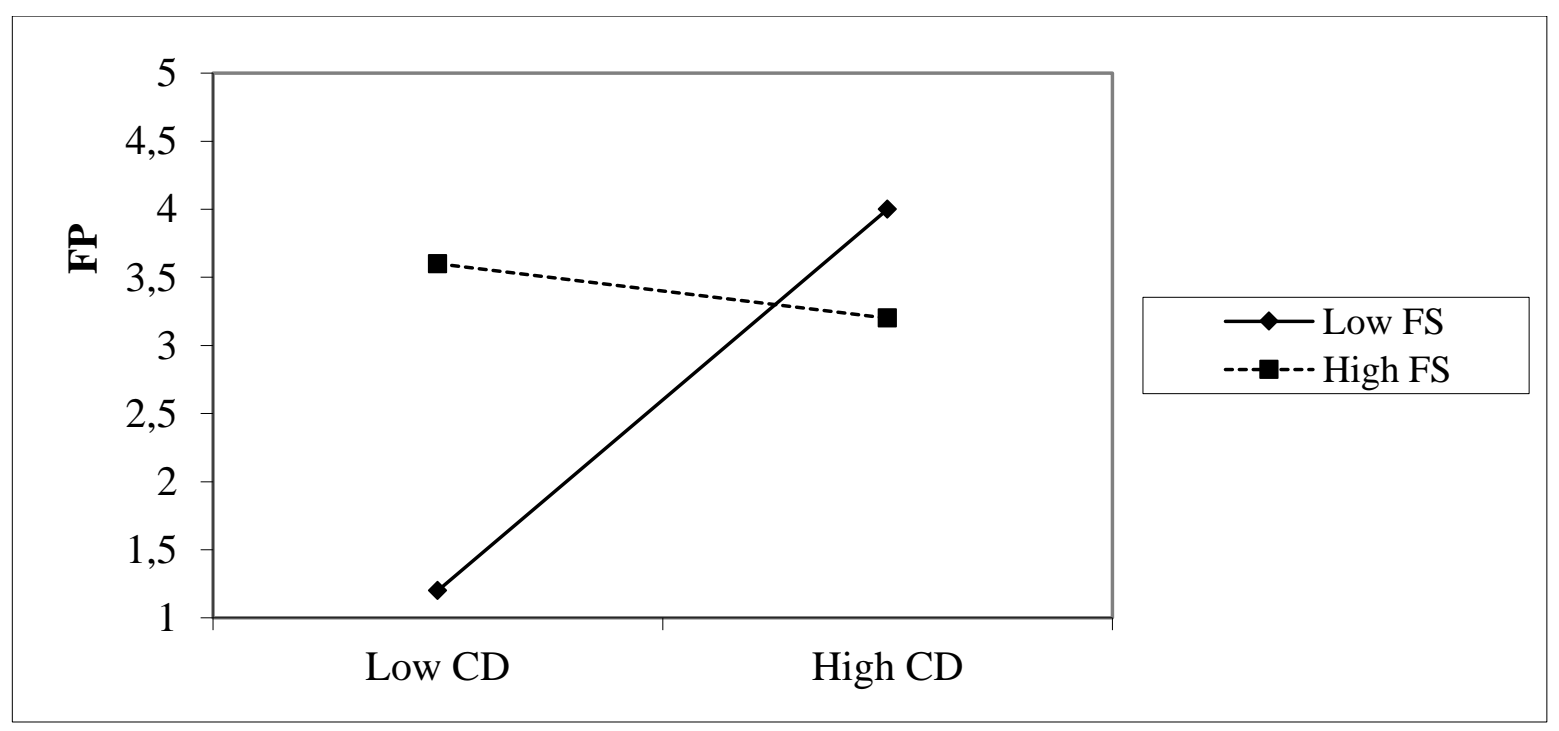

Figure 2; Nature of Moderation

Copyright (C) 2021, Journal of Advanced Research in Economics and Administrative Sciences (JAREAS), Under a Creative Commons Attribution 4.0 International License 


\section{Conclusion and Suggestion}

The study assessed the relationship between corporate diversification and the financial performance of firms listed at NSE in Kenya. Based on the findings, the study concluded that corporate diversification was a vital strategy that drives financial performance. In this case, corporate diversification was specifically defined in terms of products offered by the firms. Theoretically, the study thus contributes to market power theory which postulated a positive relationship between corporate diversification in general and financial performance. Practically, management of listed firms is suggested to have more product diversification plans since it elevates financial performance.

RBV theory asserts that the uniqueness of firms arises due to the 'bundle of resources' owned. In terms of diversification, RBV theory points out those adequate resources as a driver of diversification. The study documented firm size as a buffering moderator given corporate diversification and financial performance linkage of listed firms in Kenya. The study thus contributes to RBV theory by examining the effect of interaction between firm size defined in terms of total assets and corporate diversification on financial performance. Given the buffering moderating effect, firm size is not important as it decreases the effect of corporate diversification on financial performance. Therefore, regardless of the number of assets owned, management of listed firms is suggested to progress performance by diversifying products.

The key policymakers given the listed firms in Kenya include the capital market authority (CMA) and NSE. The findings of the study will guide the policies drafted regarding diversification by listed firms. For instance, these policymakers could be able to devise awareness programs promoting financial performance using diversification. Future research could focus on other measurements for corporate diversification, financial performance, and firm size. Other types of corporate diversification such as geographic, international, related, and unrelated could further be examined by future scholars. In terms of scope, the same study could incorporate unlisted firms in Kenya as well as those listed in securities exchanges found in the East African Community (EAC). Since most investment decisions are made by the top management in the firm, future studies could control for board characteristics as size and gender diversity.

\section{Conflict of Interest}

The authors of the article declare no conflict of interest.

\section{Funding}

This research study was not funded by any institution. The author conducted the study on their own expenses.

Copyright (C) 2021, Journal of Advanced Research in Economics and Administrative Sciences (JAREAS), Under a Creative Commons Attribution 4.0 International License 


\section{References}

Akpinar, O., \& Yigit, I. (2016). The Relationship between Diversification Strategy and Firm Performance in Developed and Emerging Economy Contexts: Evidence from Turkey, Italy and Netherlands. Economic and Social Development: Book of Proceedings, 583.

Almajali, A. Y., Alamro, S. A., \& Al-Soub, Y. Z. (2012). Factors affecting the financial performance of Jordanian insurance companies listed at Amman Stock Exchange. Journal of Management research, 4(2), 266.

Babalola, Y. A. (2013). The effect of firm size on firms profitability in Nigeria. Journal of Economics and Sustainable Development, 4(5), 90-94.

Becker-Blease, J. R., Kaen, F. R., Etebari, A., \& Baumann, H. (2010). Employees, Firm Size and Profitability of US Manufacturing Industries. Investment Management and Financial Innovations. 7(2),7-23.

Bickel, R. (2007). Multilevel analysis for applied research: It's just regression! : Guilford Press.

Chatterjee, S., \& Wernerfelt, B. (1991). The link between resources and type of diversification: Theory and evidence. Strategic Management Journal, 12(1), 33-48.

Doaei, M., Ahmad Anuar, M., \& Ismail, Z. (2014). Diversification and financial performance in Bursa Malaysia. International Journal of Management and Business Research, 4(4), 309317.

Doğan, M. (2013). Does firm size affect the firm profitability? Evidence from Turkey. Research Journal of Finance and Accounting, 4(4), 53-59.

Ghafoorifard, M., Sheykh, B., Shakibaee, M., \& Joshaghan, N. S. (2014). Assessing the relationship between firm size, age and financial performance in listed companies on Tehran Stock Exchange. International Journal of Scientific Management and Development, 2(11), 631-635.

Graham, J., Smart, S., \& Megginson, W. (2010). Corporate finance: Linking theory to what companies do. South-Western Pub.

Hunjra, A. I., Butt, B. Z., \& Rehman, K. U. (2010). Financial management practices and their impact on organizational performance. World Applied Sciences Journal, 9(9), 997-1002.

Iqbal, A., Hameed, I., \& Qadeer, M. (2012). Impact of diversification on firms' performance. American Journal of Scientific Research, 80, 42-53.

Jónsson, B. (2007). Does the size matter?: the relationship between size and porfitability of Icelandic firms. Bifröst Journal of Social Science. 1(3),43-60.

Jouida, S., Bouzgarrou, H., \& Hellara, S. (2017). The effects of activity and geographic diversification on performance: Evidence from French financial institutions. Research in International Business and Finance, 39, 920-939.

Kenyoru, D., Chumba, G., Chumba, S., Finance, M., \& Rotich, S. C. (2016). Effect of Product Diversification on Financial Performance of Selected Banks in Kericho Town. European Journal of Business and Management, 8(22), 126134.

Krivokapic, R., Njegomir, V., \& Stojic, D. (2017). Effects of corporate diversification on firm performance: evidence from the Serbian insurance industry. Economic researchEkonomska istraživanja, 30(1), 1224-1236.

Copyright (C) 2021, Journal of Advanced Research in Economics and Administrative Sciences (JAREAS), Under a Creative Commons Attribution 4.0 International License 
Lee, C.-C., Hsieh, M.-F., \& Yang, S.-J. (2014). The relationship between revenue diversification and bank performance: Do financial structures and financial reforms matter? Japan and the World Economy, 29, 18-35.

Lee, J. (2009). Does size matter in firm performance? Evidence from US public firms. international Journal of the economics of Business, 16(2), 189-203.

Li, H., \& Zhang, Y. (2007). The role of managers' political networking and functional experience in new venture performance: Evidence from China's transition economy. Strategic Management Journal, 28(8), 791-804.

Lins, K. V., \& Servaes, H. (2002). Is corporate diversification beneficial in emerging markets? Financial management, 5-31.

Manyuru, A., Wachira, M., \& Amata, E. (2017). The impact of corporate diversification on firm value in Kenya. African Journal of Business Management, 11(11), 241-249.

Mehmood, R., Hunjra, A. I., \& Chani, M. I. (2019). The Impact of Corporate Diversification and Financial Structure on Firm Performance: Evidence from South Asian Countries. Journal of Risk and Financial Management, 12(1), 49.

Montgomery, C. (1994). Corporate Diversification: The Journal of Economic Perspectives: California: Oxford University Press.

Nath, P., Nachiappan, S., \& Ramanathan, R. (2010). The impact of marketing capability, operations capability and diversification strategy on performance: A resource-based view. Industrial Marketing Management, 39(2), 317-329.

Niresh, A., \& Thirunavukkarasu, V. (2014). Firm size and profitability: A study of listed manufacturing firms in Sri Lanka. International Journal of Business and Management, 9(4).

Nzioka, S. (2017). The Relationship between Diversification Strategies and Capital Structure of Non-Financial Firms Listed At the NSE. KCA University.

Oyekunle Oyewobi, L., Olukemi Windapo, A., \& Cattell, K. S. (2013). Impact of business diversification on South African construction companies' corporate performance. Journal of Financial Management of Property and Construction, 18(2), 110-127.

Pavić, I., \& Pervan, M. (2010). Effects of corporate diversification on its performance: The case of Croatian non-life insurance industry. Ekonomska misao i praksa(1), 49-66.

Phung, D. N., \& Mishra, A. V. (2016). Ownership structure and firm performance: Evidence from Vietnamese listed firms. Australian Economic Papers, 55(1), 63-98.

Saleh, M., Zahirdin, G., \& Octaviani, E. (2017). Ownership structure and corporate performance: evidence from property and real estate public companies in Indonesia. Investment Management \& Financial Innovations, 14(2), 252.

Salma, U., \& Hussain, A. (2018). A Comparative Study on Corporate Diversification and Firm Performance across South Asian Countries. Journal of Accounting \& Marketing, 7, 1-7.

Seifi, A., Moosavi, S. V., \& Ardestani, E. (2012). A Conceptual Framework for Evaluating New Business Opportunities for Corporate Diversification. Journal of Enterprise Transformation, 2(2), 105-129.

Shyu, J., \& Chen, Y.-L. (2009). Diversification, performance, and the corporate life cycle. Emerging Markets Finance and Trade, 45(6), 57-68.

Copyright (C) 2021, Journal of Advanced Research in Economics and Administrative Sciences (JAREAS), Under a Creative Commons Attribution 4.0 International License 
Stock, J. H., \& Watson, M. W. (2003). Introduction to econometrics (Vol. 104): Addison Wesley Boston.

Tabash, M. I., \& Dhankar, R. S. (2014). Islamic Financial Development and Economic Growth-Empirical Evidence from United Arab Emirates. Journal of Emerging Economies and Islamic Research, 2(3), 15-31.

Untoro, W., \& Rahardian, R. (2015). Firm Size and Diversification Strategies: Does Labor Intensity Matter? Corporate Ownership \& Control, 327.

Vijayakumar, A., \& Tamizhselvan, P. (2010). Corporate size and profitability: An empirical analysis. Journal for Bloomers of Research, 3(1), 44-53.

Zikmund, W. G., Babin, B. J., Carr, J. C., Adhikari, A., \& Griffin, M. (2013). Business Research Methods A South-asian Perspective: Cengage Learning. 